\author{
V.V. Kuklina ${ }^{1,2}$, A.A. Petrov ${ }^{3}$, I.N. Bilichenko ${ }^{2 *}$, \\ V.N. Bogdanov ${ }^{2}$, D.V. Kobylkin ${ }^{2}$, N.E. Krasnoshtanova ${ }^{2}$ \\ ${ }^{1}$ Department of Geography, George Washington University, Washington, USA; \\ ${ }^{2}$ Lab of Natural Resource Management and Political Geography, V.B. Sochava Institute of Geography SB RAS, Irkutsk, Russia; \\ ${ }^{3}$ ARCTICenter and Department of Geography, University of Northern Iowa, Iowa, USA \\ Corresponding author: irinabilnik@mail.ru
}

\title{
Informal roads as social-ecological-technological systems (SETS): sustainability challenges and impact on landscape transformations
}

\begin{abstract}
Following the call to mobilize studies of social-ecological systems and sociotechnical systems, the paper presents the case for studying integrated social-ecological-technological systems (SETS), and dynamic systems that include social, natural and technological (engineering) elements. Using the case study of informal roads in the Baikal region, authors of the article argue that re-focusing on SETS creates additional synergies and convergence options to improve the understanding of coupled systems and infrastructure in particular. Historically, transportation infrastructure has contributed to changes in natural and social systems of Northern Eurasia: Trans-Siberian and Baikal-Amur railroads and Eastern Siberia-Pacific Ocean and Power of Siberia pipelines have been the main drivers of social-ecological transitions. At the local scale, informal roads serve as one of the most illustrative and characteristic examples of SETS. The examination of development and transformation of the informal roads allows exploring the interactions between socioeconomic processes, ecological dynamics and technological advances. The variety of informal roads reflects the importance of specific social, natural or technological factors in the SETS transformation largely unconditioned by policy and regulations thus providing a unique opportunity to better understand sustainability challenges facing infrastructure-based SETS. Relying on interviews and in-situ observations conducted in 2019 in the Baikal region, the following factors affecting sustainability of informal road SETS were identified: social (identification of actors involved in location, construction, maintenance, use and abandonment of informal roads), technological (road cover, width, frequency and nature of use by different kinds of vehicles), environmental (geomorphology and landscape sensitivity and vulnerability). The sustainability challenges of SETS development and transformations are found in changing mobility practices, social structure and economies of local communities, increased occurrences of forest fires and development of erosion and permafrost degradation in local environment and push for development of new technologies of transportation and communication.
\end{abstract}

Keywords: informal roads, benefit-sharing, extractive industries, transportation infrastructure, indigenous people, transformation of geosystems.

\section{Introduction}

Development of transportation infrastructure has been in the focus of attention of researchers for a long time. Researchers recognize both positive and negative effects that transportation infrastructure brings. The issues of 'infrastructure violence', 'tunnel effects of infrastructure' have been discussed in the southern context, contagious development has been in the center of attention of studies in Amazonia, and the changing geopolitical map under the influence of pipeline networks has been a point of concerns in Europe. The Arctic and Subarctic environmental impact of infrastructure is rarely considered in terms of power relations. Moreover, prevailing assumption that the infrastructural development has a network character, which means connections between different nodes are more or less similar. In our study, we emphasize the access to some links is restricted or negotiated, which means it involves some power relations and subsequent hierarchies of infrastructure. Such phenomenon is evident in the resource extractive regions, such as the North of Irkutsk Region or the South of the Republic of Sakha (Yakutia) where new boom of infrastructural development was caused by construction of the Eastern Siberia-Pacific Ocean (ESPO) oil pipeline in 2008 and current construction of Power of Siberia gas pipeline.

During the fieldwork in Vershina Khandy, we travelled by roads of common use, forest roads, former geophysical line clearings, inter-settlement informal road and subsistence tracks.

In the process of the fieldwork in Tokma, we used roads of common use, federal and municipal winter roads, forest roads, former geophysical line clearings, and subsistence tracks.

These roads have distinguishable physical properties that in some cases are regulated and have to be conformed to certain requirements by low, and in some cases - used and maintained by local traditions and capacities. However, the officially existing requirements differ from real practices of maintenance and use. 
The federal winter road can be narrow and the municipal winter road can easily be blocked by a road accident.

Roads for special use, in our case, are mostly forest haul and logging roads with the former being larger than latter. They are often created along the former geophysical line clearings which explain their straight lines.

Roads with restricted use usually have a gated access point, which is sometimes enforced by security cameras, as in the case of oil service road. Their roads are patrolled, and unwelcome intruders are quickly expelled. Or the access restrictions can be formal, when there is just a local hired guard as in case of forest road near Vershina Khandy. The main purpose of the guard in this case is to make sure no illegal loggers will get on the rented forest area.

Roads with customary use are the least visible; they have fewer imprints both in summer and winter and easily destroyed by ice heave, rain, snow, or heavy vehicles. Therefore, we put them in the lowest place in our hierarchy of infrastructure. In addition, the outsiders either do not know, or do not care about rules of use and maintenance of these roads, while local communities cannot enforce their low in any form.

Road construction negatively affects the state of the landscape, damaging or destroying its natural elements, and therefore, disturbs the balance in nature [1]. Thus, road landscapes belong to direct anthropogenic complexes formed as a result of purposeful human activity in nature [2].

Addressing the need to deal with complex issues humanity faces today, researchers look for convergence of different sources of knowledge. One of such approaches is studies of social-ecologicaltechnological systems (SETS).

\section{Theoretical considerations}

We understand SETS as integrated and dynamic systems that include social-cultural, environmental, and technological-infrastructural domains. Environmental domain provides ecosystem services to the socialcultural domain, while humans apply anthropogenic impact on the environment. Chester et al. [3] estimate the environmental impacts of transportation systems, and the ways to cost-effectively minimize these impacts, by including vehicle, infrastructure, and energy production life-cycle components, in addition to operation. The technological-infrastructural domain affects the social-cultural domain by the use of technologies and infrastructure, as well as impacting on local mobility, while social perception and values are embedded in the creation and maintenance of infrastructure and technologies. Bearing capacity of infrastructure is significantly determined by environmental conditions while transformations in technologies and infrastructure cause changes in ecological flows [4] (Fig. 1).

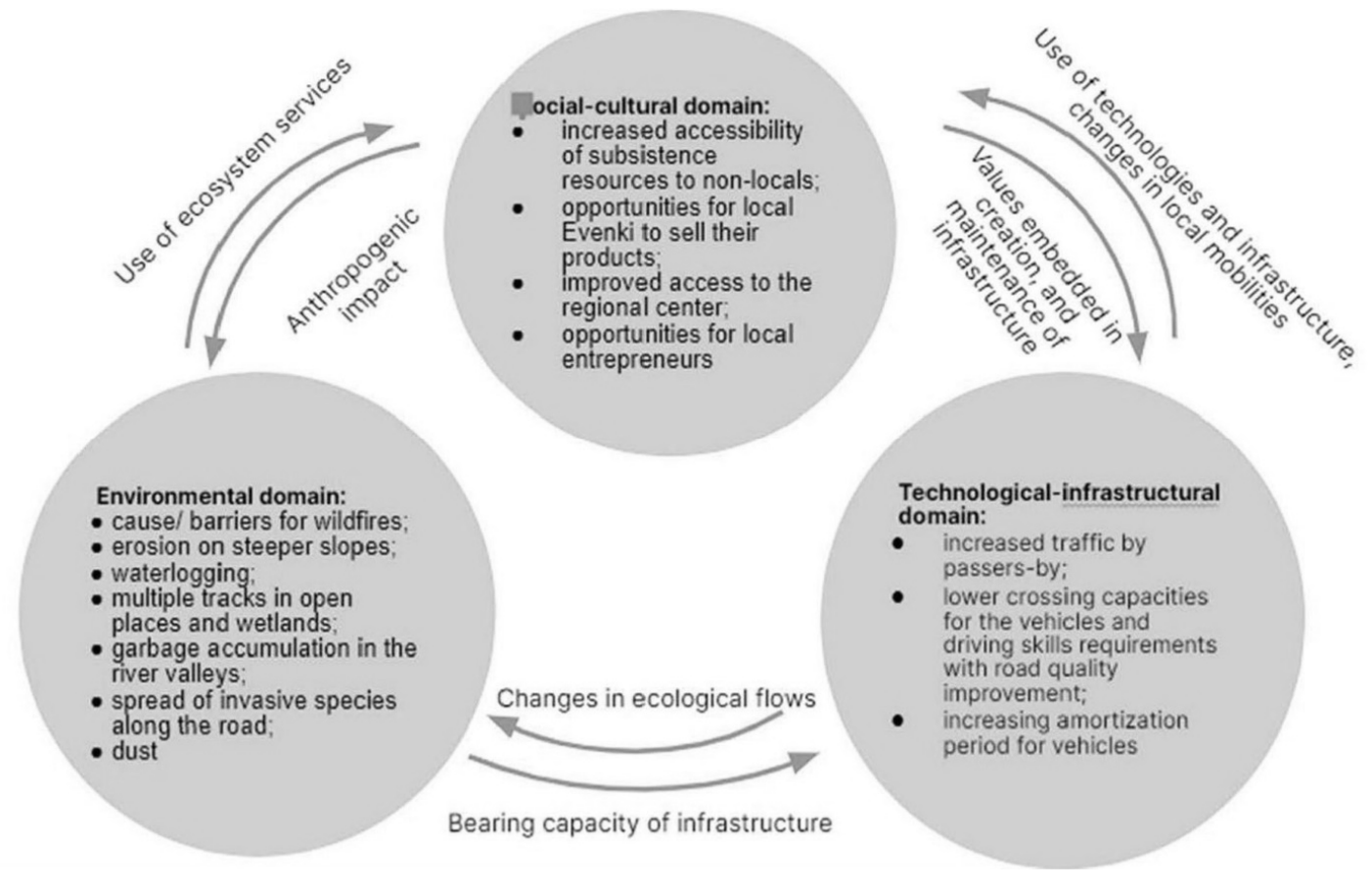

Figure 1. Study area SETS components 
Transportation networks have already been explored as the networks developing in a hierarchical pattern [5]. The same is true about electricity grid networks [6]. To analyze the structure and operations of infrastructure systems, Janssen et al. [7] use the couple infrastructure systems (CIS) framework. "Poor road quality is not just a consequence of biophysical processes, but also a consequence of choices for funding, planning, construction, use, and maintenance" [7]. As many other unbuilt and unfinished projects [8], strength of Siberia pipeline construction has not been finished yet, but has already had significant impact on local expectations, mobilities, economies, and even environment.

To study SETS, we use a panarchy metaphor for describing multi-scale social-ecological-technological interactions with patterns of stability and change within and across scales. They have specific adaptive cycles that instead of traditional within social-ecological systems phases of growth, conservation, release, and reorganization [9], they rather include growth and exploitation when the system expands, maintenance, when the system is stable, collapse - decline of a system in the current form, and reorganization - transformation of one type of SETS into another. Processes in an adaptive cycle at one scale affect adaptive cycles at other scales.

Resilience in this view is "the amount of disturbance that can be sustained before a change in system control and structure occurs - ecosystem resilience" [10].

Among the slow variables we can list growth of cedar and lichens. Among the fast variables: growth of thicket, wildfire.

\section{Study Area}

In this paper, we discuss the preliminary results of the studies of informal roads as an example of SETS. Under informal roads we understand all the transportation pathways that the remote, mostly indigenous communities use in absence of public roads [11]. The study area is located in North-Eastern Siberian taiga having similarities in taiga and bears with many other Arctic and Subarctic regions. It has harsh climatic conditions, presence of permafrost, traditional indigenous cultures, high dependency on extractive industries, and nascent elements of tourism. The dynamics of economic development are closely linked to the large infrastructure projects Baikal-Amur Mainline, Eastern Siberia-Pacific Ocean and Power of Siberia pipelines. Forestry and geological exploration companies are also active in the study sites. These activities take place on the territories of traditional land use of indigenous people of Evenki. Traditional subsistence activities of Evenki include hunting, fishing and pine nuts, berries and herbs gathering [12].

The study communities are rather small, with 54 people in Tokma and from 6 to 20 in Vershina Khandy depending on the season [13]. However, both settlements are home for Evenki, indigenous people of the North whose traditional culture depends on hunting, fishing, and gathering activities. So, the territories of traditional land use occupy significant territories, in case of Khandinskaya obshchina almost comparable with the territory of the Road Island state. The study areas are crossed by major pipelines, developed by oil and gas companies, logged by forest companies and explored by geological parties (Fig. 2).

\section{Methods}

This research is based on data from field studies in Vershina Khandy, Kazachinsko-Lenskiy district in August 2019 and in Tokma Katangskiy district of Irkutsk region in March 2020 which includes 14 in-depth interviews, both on the move, and in settlements with local residents, and participated in daily activities. The residents shared their personal stories, concerns and emotions related to the existence and use of informal roads. Travelling together by these roads using different modes of transportation gave us a glance on sensory experiences of local mobility. Also, we utilize data from previous studies in the region where we have worked since 2006 .

To make an inventory map of the study area, we used medium- and high-resolution satellite data such as Landsat and Digital Globe, multi-temporal topographic maps, infrastructure development planning documents, interviews with local residents, and drone imagery. To study dynamics of the road network development in the study areas since 1980s, students of George Washington University mapped informal roads from using Landsat imageries.

We categorized existing transportation infrastructure according to the regulations and distinguished formal, semi-formal and informal ones (Fig. 3). Then we identified different forms of ownership for understanding maintenance and use of these roads and differentiated public and private roads, rented and owned by different state agencies. In regard to accessibility, we distinguish public roads of common use, private and rented roads with limited access. The roads with special use have been created for specific purposes, but the 
access is not controlled. Subsistence and informal inter-settlement roads form specific kind of roads for traditional use that are maintained, used, and regulated according to local traditions.
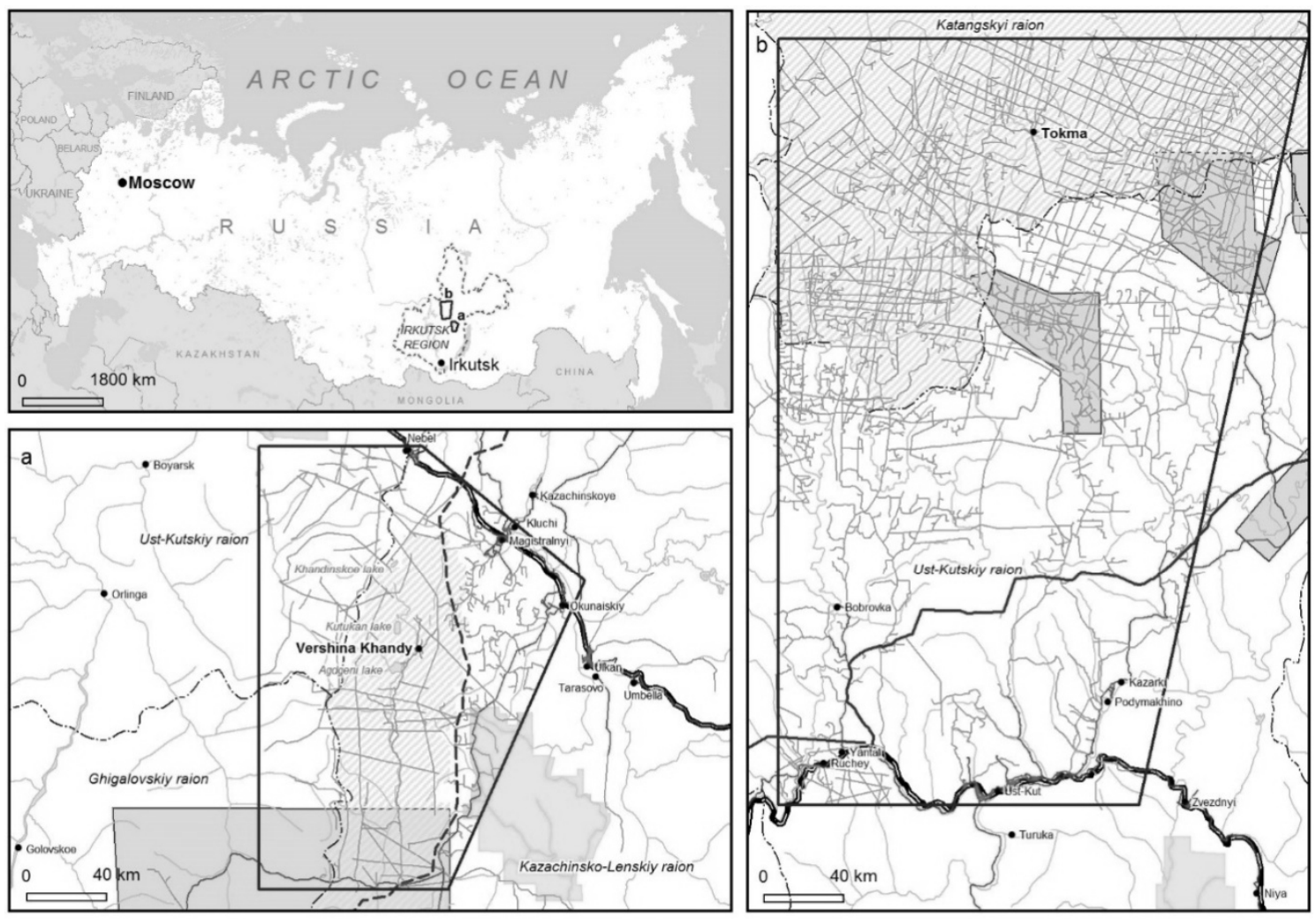

\section{Legend}

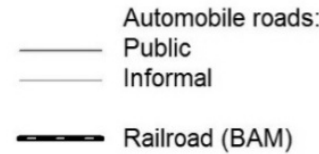

- Oil pipeline

-.- Gas pipeline under construction Gas / Oil fields

- Settlements Border of raions
Territories of traditional land use

\section{Protected Areas}

Study areas

Figure 2. Study area

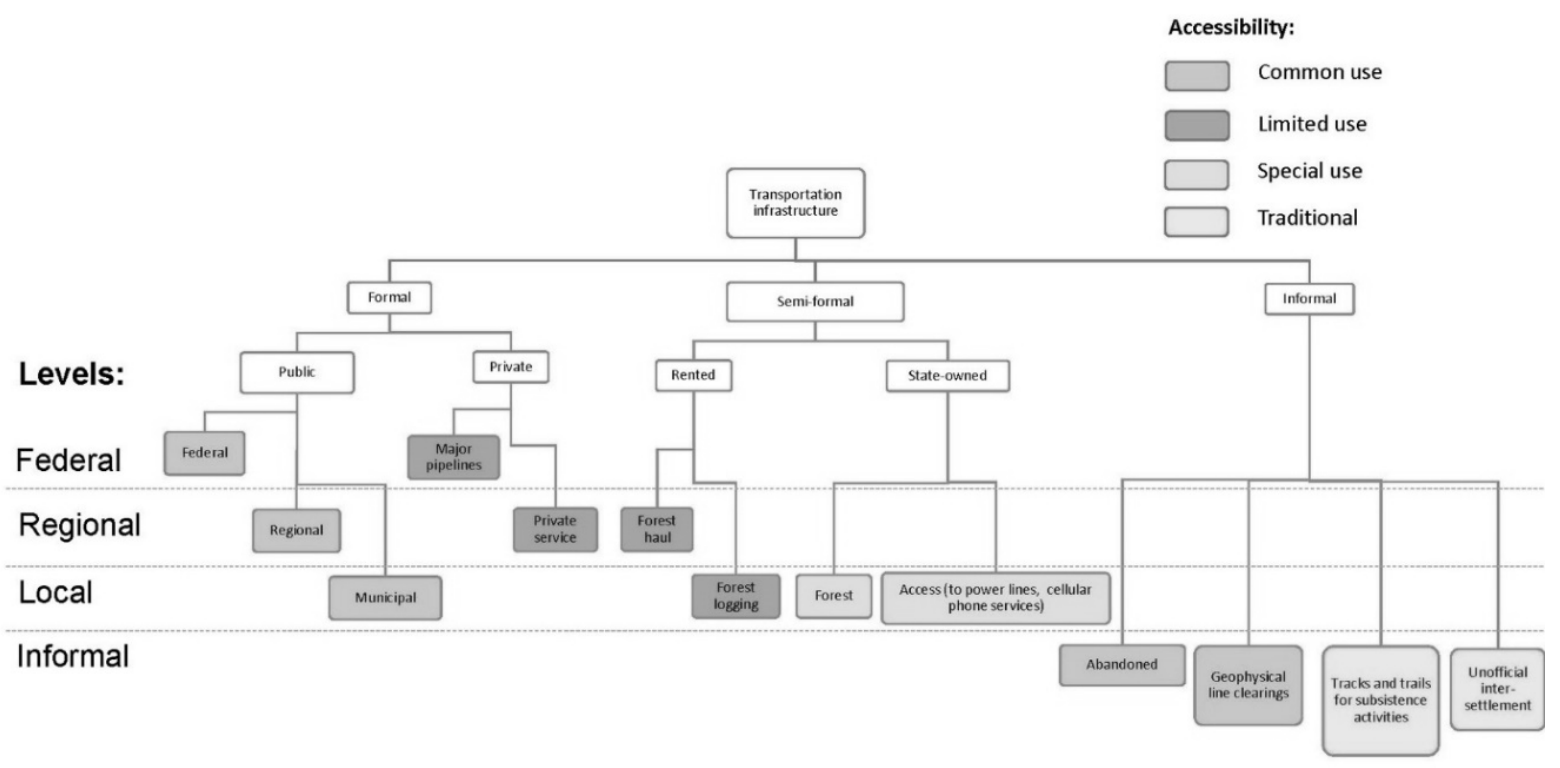

Figure 3. Informal roads classification 
Finally, we tried to identify existing hierarchies that are materialized in the forms of pavings, right-ofway and regime of access. Partially, they conform to the Russian regulations on automobile roads and their environmental impact assessment. At the federal level, we distinguish federal roads and major infrastructure objects, at the regional: roads of regional significance, private service roads and the forest haul roads. At the local level, there are municipal roads and roads for forest logging. Informal roads represent an additional level where we list not only traditional roads, but also former official roads that have been abandoned and geophysical line clearings since specific regulations concerning roads and transportation infrastructure do not apply to them.

The landscape studies included measurements of soil erosion, permafrost degradation, vegetation condition. For this analysis, we verified data from remote sensing applying a variety of cartographic material, field studies, and data from engineering geological drilling.

\section{Results}

SETS at federal, regional and local levels of spatial hierarchy have similarities with existing regulations on automobile roads and their environmental impact, including categories of roads, ecological classes, zones of impact and protection, reserve technological strip, work project and specific recommendations for measures to mitigate the negative impact. Among techno-infrastructural characteristics, there are distance, traffic volume, specifications of infrastructure objects, and availability of engineering project. The sociocultural aspects are limited by an investment plan and specific recommendations to mitigate negative social impact (Fig. 4).
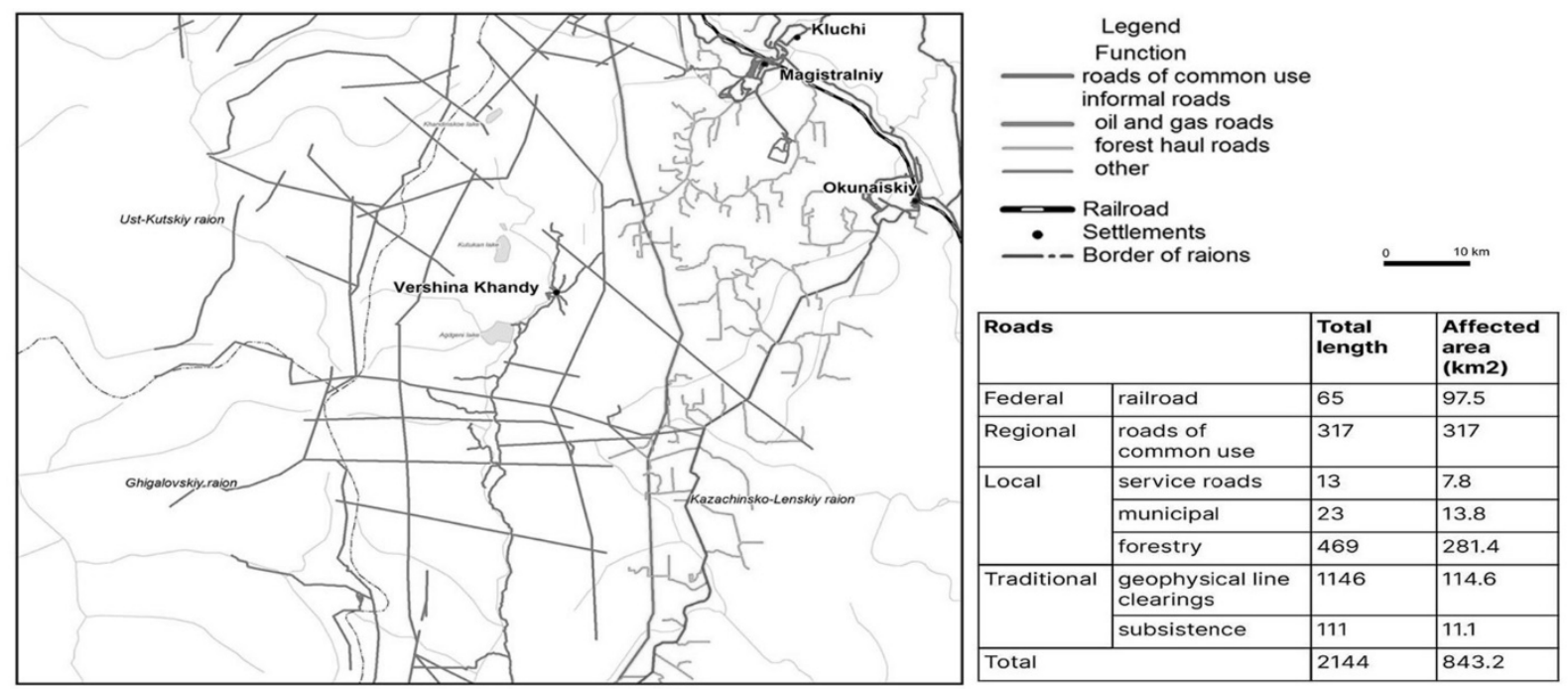

Figure 4. Informal roads level

In the study area, the infrastructure of the federal level is represented by the Baikal-Amur Mainline (Fig. 5), Eastern Siberia-Pacific Ocean oil pipeline, and Power of Siberia gas pipeline under construction.

Decisions about construction are made at the highest state or international level and take a long time to implement. For example, discussions about BAM construction started in the end of 19th century, the call to build BAM was announced by the former Soviet Secretary Leonid Brezhnev in 1974 [14], and the project was fully completed only in 2013. The BAM includes over $4300 \mathrm{~km}$ of railroad, multiple side tracks and 200 stations, linking over 60 cities and towns and crossing over 2000 bridges across the territories of six federal subjects of East Siberia and the Russian Far East. It served as an impetus for local and regional economic development, changed transportation accessibility, and led to significant environmental problems in the region $[15,16]$.

However, even before the completion of the construction, the project was heavily criticized during the 1990 s, and only state subsidies secured it from collapse.

Because construction of the major infrastructure has such profound impact across large territories, even anticipation of construction plays an important role in social dynamics $[16,17]$. 


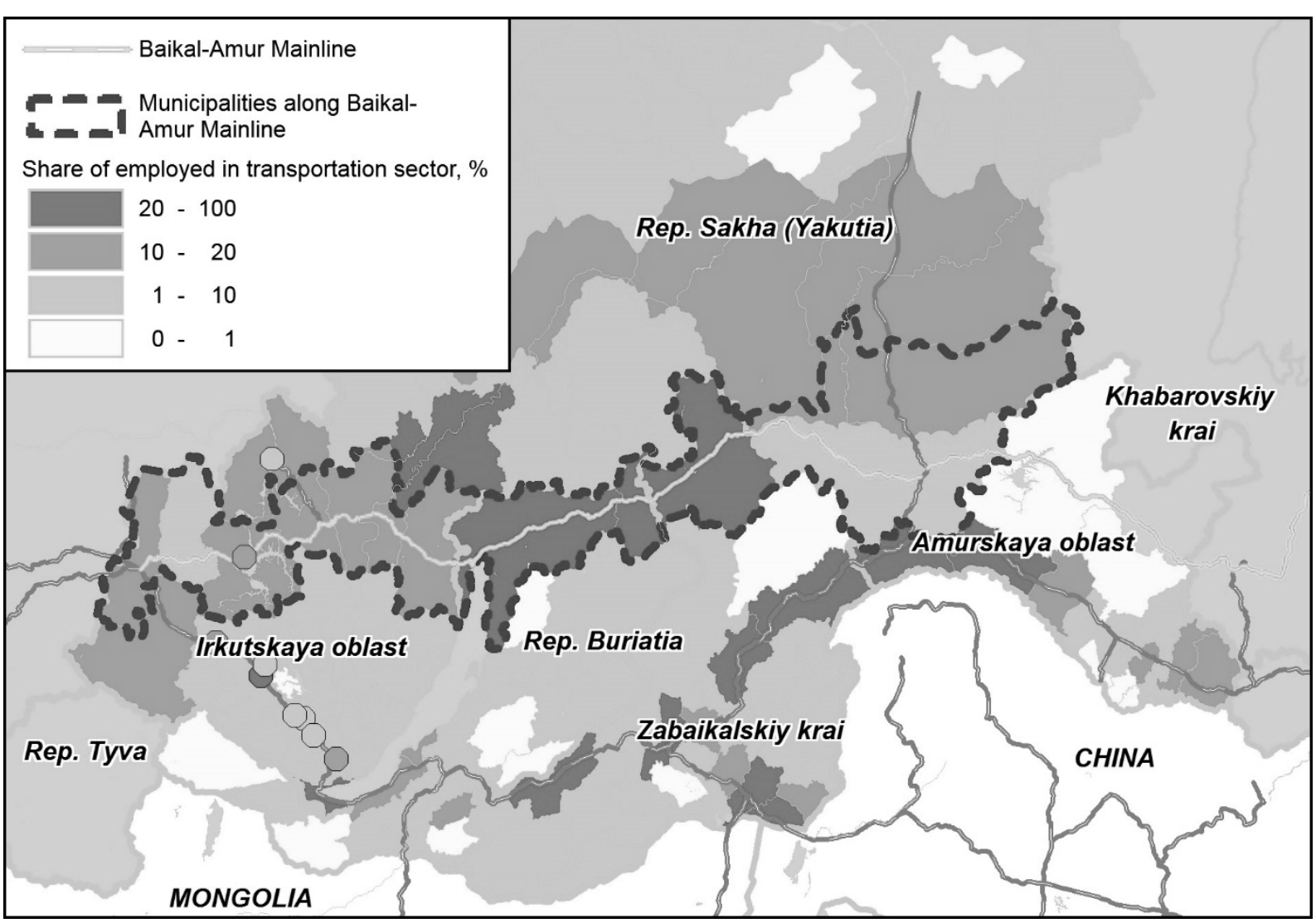

Figure 5. Study area

At the regional level, infrastructure is more adjusted to local engineering-geological conditions, and depends on major infrastructure and its configuration. In particular, we can see dramatic change in accessibility with construction of the Eastern Siberia-Pacific Ocean oil pipeline and adjacent service roads. However, the users of this private road are charged with the high price to access the road. From another side, control over the traffic and maintenance of infrastructure reduce poaching, forest wildfires.

At the local level, the development of forestry and access roads often has a seasonal and/or temporary character. They are often used by either heavy or light off-road vehicles. Lower quality of these roads leads to a shorter amortization period for vehicles. From an environmental perspective, they serve both as a barrier and cause to forest wildfires. Lack of maintenance leads to garbage accumulation and on wetlands and open areas the vehicles often create multiple tracks.

From social perspective, increased uncontrolled and unregulated accessibility along the roads for special and common use from one side increase opportunities for inter-settlement communication, access to services, opportunities to travel longer distances for subsistence activities. From another side, it leads to depletion of hunting and fishing resources due to poaching.

At the level of informal roads, we find that their share exceeds the share of the roads of all other levels combined, and the environmental impact estimated according to SNIP regulations can reach up to $12 \%$ of the territory. These informal roads are used for both traditional activities by local residents and recreational fishing and gathering by non-locals.

The main function of traditional roads is to connect dwelling with subsistence place in the best way considering available infrastructure, natural conditions, vehicle capacities, and driver's skills and abilities. That makes these roads highly adaptive to changes. Particularly, they change location depending on emerging new infrastructure, technologies, environmental and resource conditions. Usually, they are narrow (about 2-3 meters wide) and stretch over short distances. However, with the development of technologies and infrastructure and lack of resources nearby the distance can increase. The most adapted to local conditions vehicles: snowmobiles and swamp buggies that have lighter imprint in the landscape. Within the time frame, their function is carried on for multiple generations while traditional ecological knowledge and values are preserved. Therefore, they are highly dependent on the existence of local and indigenous cultures. 
To illustrate the dynamics of SETS, we take an example of the road between Zhigalovo and Ulkan settlements. It was planned to be constructed in the 19th century and depicted on the map from that period as the planned road to Bodaibo. Nonetheless, the plans have not been accomplished for almost a century.

The map of 1937 shows the absence of roads at that time. Most of the transportation and communication was still by the rivers and using traditional ways, which for Evenki was by reindeer trails.

In the 1960s, the geological explorations started in the region and led to development of geophysical line clearings.

In 1984, the main parts of the BAM were completed and forestry development along the BAM started. In addition, Krivolukskaya geological oil-gas exploration expedition was based in Zhigalovo for prospecting the area. In 1987, the Kovyktinskoye gas deposit was discovered. Used by these agencies local roads were impassable by ordinary motorized vehicles.

In 1992, TNC-British Petroleum, Interros and Irkutsk region founded collaborative Russia Petroleum enterprise for its exploration. They started permanent road construction that by 2004 was not completed. In 2011, with the changing political climate, Russia Petroleum sold license for exploration to Gasprom and the road was left for local uses.

In 2014, agreement about Strength of Siberia pipeline construction was signed between leaders of Russia and China and in 2018, Gasprom started re-construction of the road Zhigalovo - Kovyktinskoye as a part of their major infrastructure.

The investigated road from Vershina Khandy is formed by an old fishing route $(7.2 \mathrm{~km})$, an abandoned seismic line clearing $(5.3 \mathrm{~km})$, road created by locals informally $(4.0 \mathrm{~km})$, a private forest road (currently rented by Rusforest Magistralny LLC) $(18.4 \mathrm{~km})$, and a public road to the village of Magistralny $(4.7 \mathrm{~km})$.

Three types of characteristic surfaces with different relief are distinguished in this territory: denudation on wavy watersheds, the structural-erosive-denudation on the river valleys slopes, and the erosionaccumulative relief on floodplains and river terraces, lacustrine-accumulative and biogenic relief is widespread in the bottoms of the basins [18]. The studied territory has an average geomorphological hazard with a high probability of occurrence of karst, cryogenesis, planar and linear erosion processes [19]. Permafrost cracking and swelling of soils, thermokarst, and ice heaves are especially common for hollows and river basins bottoms.

Informal roads form country-road landscapes without a raised subgrade or paved surface prone to road erosion. Nearly two thirds of the road have roadside secondary birch forbs, while larch and spruce-larch moss forests with spruce form the background. In 8 kilometers from the village road lays over peatland with permafrost occurrences. In summer, local residents can cross it only by heavy or light cross-country vehicles. The road use is accompanied by thawing, watering, and subsidence of soils. At the same time, the moss cover dies, supplanted by sedges and reed grass. Local efforts to by-pass disturbed surface result in "multitracking". Ravines (erosion potholes) were observed on the sections of the road with a slope steepness reaching $10^{\circ}$. Given the width of the carriageway of informal roads (an average of $6 \mathrm{~m}$ ), the area of directly affected landscapes is approximately 1000 hectares, without taking into account indirect impact.

\section{Discussion}

Based on this short analysis of existing transportation infrastructure in the study area, its morphology and properties, we find it important to study hierarchies of infrastructure. Because uneven infrastructure access is illustrative of existing power relations; where local communities have limited options for negotiations.

Unequal status of different roads and hierarchy of relations between them are especially evident at the intersections. Unfortunately, it was impossible to take a picture of the right-of-way sign that ensures undisturbed movement of the vehicles along the oil service roads. However, the quality of their roads is also contrasting both in comparison with forest and winter roads for common use. Often, they are represented by bundles of different infrastructure components: both power lines and pipelines, or fibre-optic lanes or other objects that makes the lines large and inaccessible for the use by ordinary drivers.

Meanwhile, the service roads are often shorter, the lines are straighter, they have better location, and the other roads may toggle in parallel, contributing to the forest fragmentation. It is especially evident in Tokma area, nevertheless, in the Vershina Khandy area, we see path dependency on the previous seismic line clearings location. The gas pipeline has not been built yet, but one can assume significant disruptions in local mobilities since the line crosses the main access roads to the village. 
Hierarchies of infrastructure determine infrastructural violence, while the other users lacking power have to seek consensus and negotiate use of infrastructure. Ownership recognized only at the higher levels of hierarchy while customary low is neglected.

Such hierarchies have certain impact on landscape, such as fragmentation, contamination, and degradation and on local (im)mobilities by restricting, regulating, and channeling them.

Intersectionality of roads affects social intersectionality. The travel by roads with lower quality is not physically demanding, it also provides visible marks of power hierarchies when crossing well-maintained elements of infrastructure of higher level.

Implications of the road development for technological-infrastructural domain are increased by those who travel between BAM settlements and regional center of Irkutsk; lower crossing capacities for the vehicles and driving skills are required with road quality improvement; amortization period for vehicles increased. In the social-cultural domain, there is an increased accessibility of subsistence resources to nonlocals, opportunities for local Evenki to sell their products of subsistence activities to the passersby. Access to the regional center for the local communities significantly improved and for local entrepreneurs new opportunities were open for shipping goods. In the environmental domain, road caused erosion on steeper slopes, waterlogging in swampy areas, spread of invasive species along with the road and dust.

Based on research of SETS in the study area we distinguish the following driving forces of dynamics sets (Fig. 6).

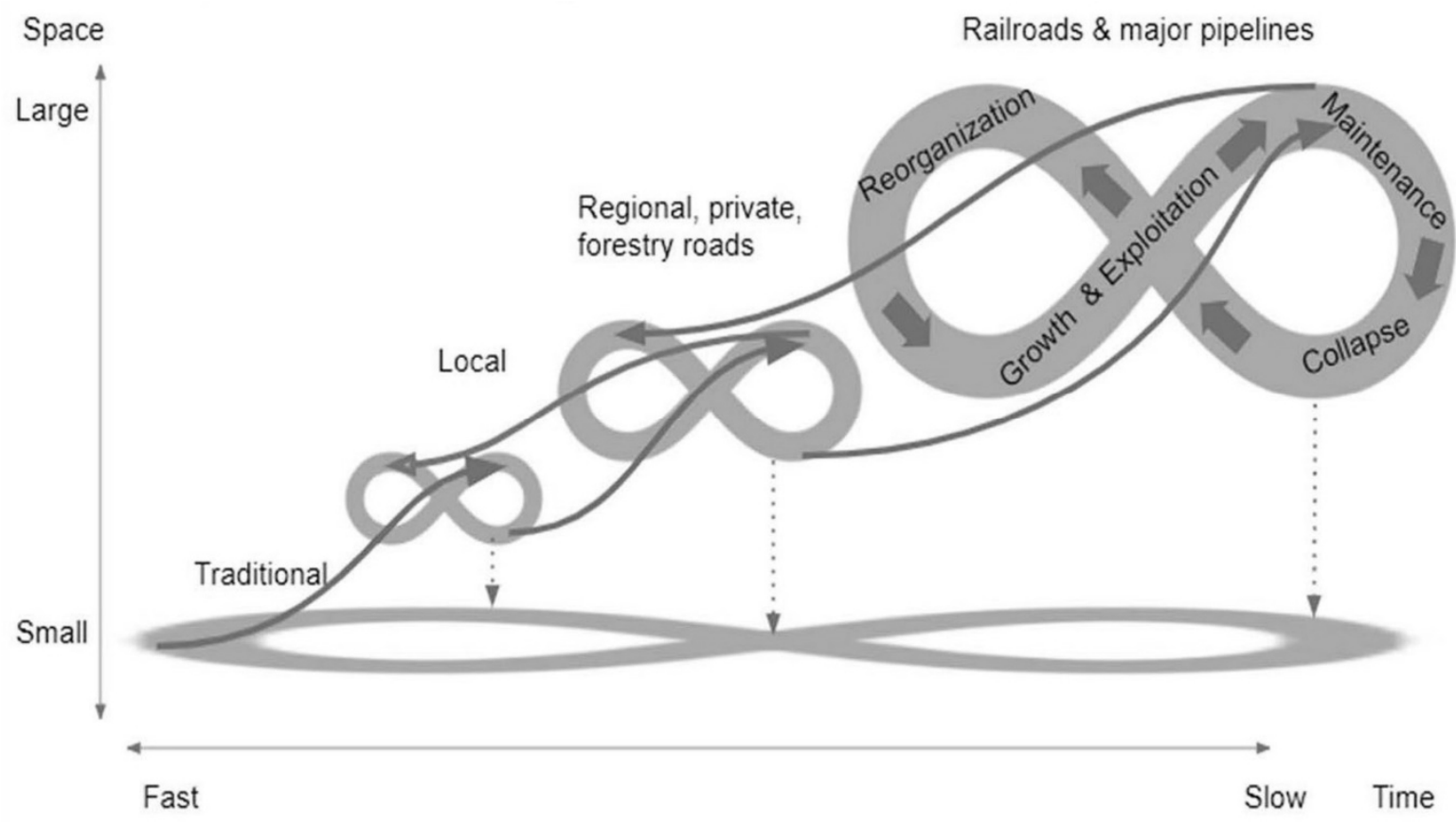

Figure 6. Dynamics in transportation SETS components of the study area

Large scale infrastructure (railroad and major pipelines) corresponds to large social-ecological systems and requires significant state and international investments for their creation and maintenance. Their relations with the lower levels are strongly hierarchical in the case study in Russia. At the regional scale, prospects of economic development which follow development of major infrastructure are important. Local SETS develop faster and have smaller cycles of functioning and can at the latter stages transform into the regional SETS, as the case with Zhigalovo - Ulkan road demonstrates.

Informal roads have the lowest scale and have both fast and slow cycles since they constantly adapt to changes at the higher scales. As for traditional roads, the most important factor for their existence is preservation of local and indigenous cultures. Some of these roads can evolve into local SETS.

Moreover, collapse of any SETS of any scale can theoretically lead to their transformation into traditional roads. Degrees of flexibility decrease with growing scale of infrastructure while the rigidity increases: federal infrastructure is the most rigid. The higher level also requires higher level of predictability (e.g. in terms of minutes for railroad). 


\section{Conclusions}

Our study demonstrates that the panarchymodel is useful for studies of SETS. In difference with the social-ecological systems approach, in studies of SETS, we emphasize importance of new technologies, maintenance efforts, crucial role of investments and social values embedded in infrastructure. Technologies and infrastructure directly affect ecological flows and human mobilities, and without their consideration the knowledge on human-nature relations will be incomplete. However, application of the same methods for studies of SETS as for SES is possible, because adaptive cycles and interactions across scales have some similarities.

More studies are needed to determine the input of each driving force and measure the interactions within SETS. Using the panarchy approach, we can better understand sustainability, resilience, and adaptive capacities of such complex systems as SETS for informed decision making and local knowledge co-production.

\section{References}

1 Мильков Ф.Н. Антропогенное ландшафтоведение, предмет изучения и современное состояние / Ф.Н. Мильков // Вопросы географии. - 1977. - Т. 106. - С. 11-27.

2 Смирных А.Г. Изменение ландшафтов при строительстве и эксплуатации автомобильных дорог в степной и сухостепной зонах Урала / А.Г. Смирных // География и природные ресурсы. — 1986. — № 2. — С. 95-101.

3 Chester M. Infrastructure and automobile shifts: positioning transit to reduce life-cycle environmental impacts for urban sustainability goals / M. Chester, S. Pincetl, Z. Elizabeth, W. Eisenstein, J. Matute // Environ. Res. Lett. — 2013. — Vol. 8. — 015041.

4 Pescaroli G. Critical infrastructure, panarchies and the vulnerability paths of cascading disasters / G. Pescaroli, D. Alexander // Natural Hazards. - 2016. - Vol. 82. - P. 175-192. https://doi.org/10.1007/s11069-016-2186-3

5 Yerra B. The Emergence of hierarchy in transportation networks / B. Yerra, D. Levinson // The Annals of regional Science. — 2005. — Vol. 39. - P. 541-553. https://doi.org/10.1007/s00168-005-0230-4

6 DeRolph C.R. City energy sheds and renewable energy in the United States / C.R. DeRolph, R.A. McManamay, A.M. Morton, S.S. Nair // Nature Sustainability. — 2019. - Vol. 5. — P. 412-420. https://doi.org/10.1038/s41893-019-0271-9

7 Janssen M.A. Highways as coupled infrastructure systems: An integrated approach to address sustainability challenges / M.A. Janssen, J. M Anderies, A. Baeza, H.L. Breetz, T. Jasinski, H.C. Shin, S. Vallury // Sustainable and Resilient Infrastructure. 2019. - P. 1-12. https://doi.org/10.1080/23789689.2019.1708181

8 Carse A. Unbuilt and Unfinished: The Temporalities of Infrastructure / A. Carse, D. Kneas // Environment and Society. 2019. - Vol. 10. - P. 9-28. https://doi.org/10.3167/ares.2019.100102

9 Holling C.S. The resilience of terrestrial ecosystems: local surprise and global change / C.S. Holling // Sustainable development of biosphere / Eds. W.C. Clark, R.E. Munn. — Cambridge: Cambridge University Press, 1986. — P. $292-317$.

10 Holling C.S. Panarchy: understanding transformations in human and natural systems / C.S. Holling, L.H. Gunderson. Washington, DC: Island Press, 2002. - $536 \mathrm{p}$.

11 Kuklina V. Mobilizing Benefit Sharing through Transportation Infrastructure: Informal Roads, Extractive Industries and Benefit Sharing in the Irkutsk Oil and Gas Region, Russia / V. Kuklina, A. Petrov, N. Krasnoshtanova, V. Bogdanov // Resources. 2020. — Vol. 9. - P. 21. https://doi.org/10.3390/resources9030021

12 Рагулина М.В. Коренные этносы сибирской тайги: мотивация и структура природопользования (на примере тофаларов и эвенков Иркутской области) / М.В. Рагулина. - Новосибирск: Изд-во СО РАН, 2000. — 163 с.

13 Вяткина Ю. Исчезать не собираемся. Коренная эвенкийка о жизни иркутского севера / Ю. Вяткина // Газета «Аргументы и Факты». — 2017. — Вып. 37. — Режим доступа: https://irk.aif.ru/society/ischezat_ne_sobiraemsya_ korennaya_evenkiyka_-_o_zhizni_irkutskogo_severa

14 Ward C. Brezhnev's Folly: The Building of BAM and the Late Soviet Socialism / C. Ward. — Pittsburg: University of Pittsburg Press, 2009. - 240 p.

15 Белкин Е.В. Формирование населения в зоне БАМ. (Демографическое развитие зоны БАМ) / Е.В. Белкин, Ф.Э. Шереги. - М.: Мысль, 1985. - 149 с.

16 Байкалов Н. С. Обживая стройку века: пространство повседневности и жилищная мобильность строителей БайкалоАмурской железнодорожной магистрали (1970-1980-е гг.) / Н.С. Байкалов // Новейшая история России. — 2018. — № 4. C. 998-1016. https://doi.org/10.21638/11701/spbu24.2018.414

17 Байкалов Н.С. Формирование социальной инфраструктуры поселений Бурятского участка БАМа (1974-1989 гг.)/ Н.С. Байкалов. - Улан-Удэ: Изд-во Бурят. гос. ун-та, 2007. — 20 с.

18 Экологическое ориентированное планирование землепользования в Байкальском регионе. Ковыктинское газоконденсатное месторождение / отв. ред. Е.Г. Суворов, С.А. Макаров. - Иркутск: Изд-во Ин-та географии СО РАН, 2004. $159 \mathrm{c}$.

19 Кузьмин С.Б. Принципы районирования Байкальского региона по опасным геоморфологическим процессам в целях их картографирования / С.Б. Кузьмин, Д.А. Лопаткин // Геодезия и картография. — 2018. — Т. 79, № 2. — С. $22-35$. 


\title{
В.В. Куклина, А.А. Петров, И.Н. Биличенко, В.Н. Богданов, Д.В. Кобылкин, Н.Е. Красноштанова \\ Әлеуметтік, экологиялық және технологиялық жүйелер (ӘЭТЖ) ретінде бейресми жолдар: тұрақты даму мәселелері және ландшафттың өзгеруіне әсері
}

\begin{abstract}
Әлеуметтік-экологиялық жүйелер мен әлеуметтік-техникалық жүйелерді зерттеуді тереңдету міндеттерін басшылыққа ала отырып, мақала авторлары Байкал аймағындағы бейресми жолдардың әлеуметтік, табиғи және технологиялық (инженерлік) элементтерін қамтитын әлеуметтікэкологиялық-технологиялық жүйелерге (ӘЭТЖ) жан-жақты тақырыптық талдау ұсынған. Сонымен қатар олардың пікірінше қайта бағдарлану, атап айтқанда, ӘЭТЖ байланысты жүйелер мен инфрақұрылымды түсінуді жақсарту үшін өзара әрекеттесу мен конвергенция үшін қосымша мүмкіндіктер жасайды деп көрсетеді. Тарихи тұрғыдан алғанда, көлік инфрақұрылымы Солтүстік Еуразияның табиғи және әлеуметтік жүйелерінің өзгеруіне ықпал етті: Транссібір және Байкал-Амур темір жолдары, ал қазіргі уақытта Шығыс Сібір - Тынық мұхиты мен Сібір қуаты құбырлары әлеуметтік-экологиялық қайта құрудың негізгі қозғаушы күштері болды. Жергілікті жерлерде бейресми жолдар ӘЭТЖ ең жарқын және сипатты үлгілерінің бірі болып табылады. Бейресми жолдардың дамуы мен өзгеруін зерттеу әлеуметтік-экономикалық процестер, экологиялық динамика және технологиялық прогресс арасындағы қатынастарды зерттеуге мүмкіндік береді. Осылайша, бейресми жолдардың әртүрлілігі нақты әлеуметтік, табиғи немесе технологиялық факторлардың саясат пен ережелерден туындамайтындығының маңыздылығын көрсетеді, бұл инфрақұрылымдық жиынтықтардың тұрақтылық мәселелерін жақсы түсінуге мүмкіндік береді. Байкал аймағында 2019 жылы жүргізілген сұхбаттар мен бақылаулар бейресми жолдардың тұрақтылығына әсер ететін мына факторлар анықталған: әлеуметтік (бейресми жолдарды орналастыруға, салуға, қызмет көрсетуге, пайдалануға және одан бас тартуға қатысатын субъектілерді анықтау), технологиялық (жол жамылғысы, ені, жиілігі және әр түрлі көлік түрлерін пайдалану сипаты), экологиялық (геоморфология, ландшафттың осалдығы және бұзылуы). ӘЭТЖ дамуы мен қайта құрылуының тұрақтылығы мәселелері көлік қозғалысының қалыптасқан тәжірибесін, жергілікті қоғамдастықтардың әлеуметтік құрылымы мен экономикасын өзгерту, орман өрттерінің көбеюі және осы аумақта мәңгі тоңның эрозиясы мен деградациясының дамуы, сондай-ақ көлік пен байланыстың жаңа технологияларын дамытуды жоспарлау болып табылады.
\end{abstract}

Кілm сөздер: бейресми жолдар, пайданы бөлу, кен өндіруші кәсіпорын, көлік инфрақұрылымы, байырғы халықтар, геожүйелерді қайта құру.

В.В. Куклина, А.А. Петров, И.Н. Биличенко, В.Н. Богданов, Д.В. Кобылкин, Н.Е. Красноштанова

\section{Неформальные дороги как социальные, экологические и технологические системы (СЭТС): проблематика устойчивого развития и влияние на преобразования ландшафта}

Руководствуясь задачами углубления исследования социально-экологических систем и социотехниче-
ских систем, авторы статьи представили комплексный тематический анализ социально-эколого-
технологических систем (СЭТС) и динамических систем, включающих социальные, природные и тех-
нологические (инженерные) элементы неформальных дорог в Байкальском регионе. Кроме этого, по
их утверждению, переориентация на СЭТС создает дополнительные возможности взаимодействия и
конвергенции для улучшения понимания сопряжённых систем и инфраструктуры, в частности. Исто-
рически сложилось так, что транспортная инфраструктура, в целом, способствовала изменениям в
природных и социальных системах в Северной Евразии: Транссибирская и Байкало-Амурская желез-
ные дороги, а в настоящее время трубопроводы Восточная Сибирь- Тихий океан и Сила Сибири бы-
ли основными движущими силами социально-экологических преобразований. В местном масштабе
неформальные дороги служат одним из наиболее ярких и характерных примеров СЭТС. Изучение
развития и трансформации неформальных дорог позволяет исследовать взаимосвязи между социаль-
но-экономическими процессами, экологической динамикой и технологическим прогрессом. Таким
образом, разнообразие неформальных дорог демонстрирует важность конкретных социальных, при-
родных или технологических факторов в трансформации СЭТС, в значительной степени не обуслов-
ленных политикой и нормативными актами, предоставляя уникальную возможность для лучшего по-
нимания проблем устойчивости, с которыми сталкиваются инфраструктурные СЭТС. Проведенные в
2019 г. в Байкальском регионе интервью и наблюдения на местах позволили выявить следующие фак-
торы, влияющие на устойчивость неформальных дорог СЭТС: социальные (выявление субъектов,
участвующих в размещении, строительстве, обслуживании, использовании и отказе от неформальных 
дорог), технологические (дорожное покрытие, ширина, частота и характер использования различными видами транспорта), экология (геоморфология, уязвимость и нарушенность ландшафта). Проблемы устойчивости развития и преобразований СЭТС заключаются в изменении сложившейся практики передвижения транспорта, социальной структуры и экономики местных сообществ, учащении лесных пожаров и развитии эрозии и деградации вечной мерзлоты на данной территории, а также в стимулировании развития новых технологий транспорта и связи.

Ключевые слова: неформальные дороги, распределение выгод, добывающая промышленность, транспортная инфраструктура, коренные народы, трансформация геосистем.

\section{References}

1 Milkov, F.N. (1977). Antropogennoe landshaftovedenie, predmet izucheniia i sovremennoe sostoianie [Anthropogenic landscape science, the subject of study, and the current state]. Voprosy geografii-Geographic issues, 106, 11-27 [in Russian].

2 Smirnykh, A.G. (1986). Izmenenie landshaftov pri stroitelstve i ekspluatatsii avtomobilnykh dorog v stepnoi i sukhostepnoi zonakh Urala [Change of landscapes during the construction and operation of highways in the steppe and dry-steppe zones of the Ural]. Geografiia i prirodnye resursy - Geography and natural resources, 2, 95-101 [in Russian].

3 Chester, M., Pincetl S., Elizabeth, Z., Eisenstein, W., \& Matute, J. (2013). Infrastructure and automobile shifts: positioning transit to reduce life-cycle environmental impacts for urban sustainability goals. Environ. Res. Lett., 8, 01504.

4 Pescaroli, G., \& Alexander, D. (2016). Critical infrastructure, panarchies and the vulnerability paths of cascading disasters. Nat. Hazards, 82, 175-192. https://doi.org/10.1007/s11069-016-2186-3

5 Yerra, B., \& Levinson, D. (2005). The Emergence of hierarchy in transportation networks. The Annals of regional Science, 39, 541-553. https://doi.org/10.1007/s00168-005-0230-4

6 DeRolph, C. R., McManamay, R. A., Morton, A. M., \& Nair, S. S. (2019). City energysheds and renewable energy in the United States. Nat. Sust., 2 (5), 412-420. https://doi.org/10.1038/s41893-019-0271-9

7 Janssen, M. A., Anderies, J. M., Baeza, A., Breetz, H. L., Jasinski, T., Shin, H. C., \& Vallury, S. (2019). Highways as coupled infrastructure systems: An integrated approach to address sustainability challenges. Sustainable and Resilient Infrastructure, $1-$ 12. https://doi.org/10.1080/23789689.2019.1708181

8 Carse, A., \& Kneas, D. (2019). Unbuilt and Unfinished: The Temporalities of Infrastructure. Environment and Society, 10 (1), 9-28. https://doi.org/10.3167/ares.2019.100102

9 Holling, C.S. (1986). The resilience of terrestrial ecosystems: local surprise and global change. Sustainable development of biosphere. W.C. Clark, R.E. Munn (Eds.). Cambridge: Cambridge University Press.

10 Holling, C. S., \& Gunderson, L.H. (2002). Panarchy: understanding transformations in human and natural systems. Washington, DC: Island Press.

11 Kuklina, V., Petrov, A., Krasnoshtanova, N., \& Bogdanov, V. (2020). Mobilizing Benefit Sharing through Transportation Infrastructure: Informal Roads, Extractive Industries and Benefit Sharing in the Irkutsk Oil and Gas Region, Russia. Resources, 9 (3), 21. https://doi.org/10.3390/resources9030021

12 Ragulina, M.V. (2000). Korennye etnosy sibirskoi taigi. Motivatsiia i struktura prirodopolzovaniia (na primere tofalarov $i$ evenkov Irkutskoi oblasti) [Indigenous ethnic groups of the Siberian taiga: motivation and structure of nature management (on the example of the Tofalars and Evenks of the Irkutsk region)]. Novosibirsk: Izdatelstvo SO RAN [in Russian].

13 Viatkina, Y. (2017). Ischezat ne sobiraemsia. Korennaia evenkiika o zhizni irkutskogo severa [We are not going to disappear. The Indigenous Evenki is about the Life of the Irkutsk North]. Retrieved from: https://irk.aif.ru/society/ischezat_ne_sobiraemsya_korennaya_evenkiyka_-_o_zhizni_irkutskogo_severa [in Russian]. Press.

14 Ward, C. (2009). Brezhnev's Folly: The Building of BAM and the Late Soviet Socialism. Pittsburg: University of Pittsburg

15 Belkin, E.V. \& Sheregi, F.E. (1985). Formirovanie naseleniia v zone BAM [Demographic Development in the BAM Zone]. Moscow: Mysl [in Russian].

16 Baikalov, N.S. (2018). Obzhivaia stroiku veka: prostranstvo povsednevnosti i zhilishchnaia amobilnost stroitelei BaikaloAmurskoi zheleznodorozhnoi magistrali (1970-1980-e gg.) ["Living the Project of a Century": The Space of Everyday Life and Housing Mobility of the Builders of the Baikal-Amur Railway (1970-1980s)]. Noveishaia istoriia Rossii - Modern History of Russia, 4, 998-1016. https://doi.org/10.21638/11701/spbu24.2018.414 [in Russian].

17 Baikalov, N.S. (2007). Formirovanie sotsialnoi infrastruktury poselenii Buriatskogo uchastka BAMa [Formation of the Social Infrastructure of BAM Settlements within the Buryat Segment]. Ulan-Ude: Buryat State University Publishing Department [in Russian].

18 Suvorov, E.G., \& Makarov, S.A. (Eds.) (2004). Ekologicheskoe orientirovannoe planirovanie zemlepolzovaniia v Baikalskom regione. Kovyktinskoe gazokondensatnoe mestorozhdenie (Environmental Oriented Land Use Planning in the Baikal Region. Kovykta Gas Condensate Field)]. Irkutsk: Institut geografii Sibirskogo otdeleniia Rossiiskoi akademii nauk [in Russian].

19 Kuzmin, S.B., \& Lopatkin, D.A. (2018). Printsipy raionirovaniia Baikalskogo regiona po opasnym geomorfologicheskim protsessam $\mathrm{v}$ tseliakh ikh kartografirovaniia [Principles of regionalization of the Baikal region by hazardous geomorphological processes for the purpose of mapping them]. Geodeziia i kartografiia - Geodesy and Cartography, 79 (2), $22-35$ [in Russian]. 